\title{
Cristianismo e Razão de Estado no Renascimento Lusiada (*)
}

\author{
Miguel Reale
}

Nascido em uma terra que surgiu para o Ocidente em plena época renascentista, quando Portugal se projetava sobranceiramente no cenário europeu por seus feitos de armas e sua cultura, julgamos de bom alvitre indagar do significado e do alcance da "Razão de Estado" na história do Império Lusíada, cuja história durante mais de três séculos se confunde com a do Brasil.

No processo do "milagre português", naquele tão breve espaço de tempo que fez de um pequeno povo, com menos de dois milhões de homens, o senhor dos mares da África, da Ásia e da América, deixando sinais maravilhosos de seu gênio criador na arquitetura e nas artes plásticas, no direito e nas letras, na ciência náutica e na obra colonizadora, participando vivamente das correntes espirituais da época, cabe esclarecer e determinar como se compuzeram as exigências ideais do Cristianismo e as necessidades urgentes e pragmáticas da construção imperial.

( ${ }^{*}$ Comunicação apresentada ao Congresso Internacional de Estudos Humanísticos reunido em Roma, em Abril de 1952, para tratar do tema: "Cristianismo e Razão de Estado no pensamento e na arte do Humanismo e do Renascimento". 
Nessa ordem de pesquiza, além de seu significado universal para o esclarecimento de um aspécto dos mais relevantes na história do homem moderno, é possível que se encontrem também motivos para iluminar os pressupostos da estrutura e da formacão culturais do poves brasileiro, que, não obstante o inflluxo benéfico poste riormente recebido de outros focos de civilização, guard:; em suas raizes o impulso fundamental da formação ibérica.

Mesmo que Portugal tivesse se notabilizado tão sómente pelas descobertas marítimas, mantendo-se impermeável às tendências filosóficas e artisticas da éra renascentista, ainda assim seria oportuna a tese que suscitamos, pois o Renascimento significou também insatisfação do conhecido, amor do risco e da aventura, verticalizando-se em personalidades fortemente talhadas para a ação. Cumpre, no entanto, ponderar que as descobertas prodigiosas de terras e mares não foĩ um episódio isolado ou marginal na história portuguesa, mas antes um acon cimento enquadrado em um sistema global de vida marcado pela consciência dos novos tempos.

Sendo um dos primeiros Estados Modernos nítidamente estruturado sôbre uma base nacional, Portugal í่ revela notáveis elementos de formação cultural no século XV, em multiplos domínios da atividade espiritual. Como bem observa Malheiro Dias, os descobrimentos portugueses não foram o resultado de uma esporádica aventura, tomado êste termo na sua acepção vulgar, mas o fruto de um plano nacional, a que presidiam concepcões geográficas arrojadas, desenvolvidas por um trabalho científico de grande envergadura. A imponente história daqueles feitos continuará ininteligivel enquanto não for integrada na cultura universitária, colocando-se os sábios no primeiro plano, ao lado dos heróis. (1)

(1) História da Colonização Portugutsa do Brasil - Ediçăo monumental comemorativa do primeiro centenário da indepen- 
A maturidade espiritual revela-se pela capacidade de participação a uma multiplicidade de esferas axiológicas, sendo quasi incompreensível que um povo se mostre superior apenas em um plano exclusivo das realizações humanas. No caso ora considerado, devemos reconhecer: que às navegações de Bartolomeu Dias e de Vasco da Gama corresponde o éco de esplendidas afirmações no campo arquitetônico (bastaria lembrar o mosteiro dos Jerônimos), na pintura de Nuno Gonçalves, no teatro de GIL Vicente, na prosa de Damião de Goes e de João de Barros, na cultura humanística de ANDRÉ DE GouveIA, mestre de Rabelais e Montaigne (2), no saber jurídico de Antônio DE GouveIA, jurisconsulto, filósofo, professor da Universidade de Paris, um dos mentores da Escola de CuJÁcro; na dúvida fecunda do "Quod nihil scitur" de Francisco SANchez; para culminar na lírica e na epopéia de Luss de Camões.

Naquele Portugal de grandes reis mecenas, dados às letras e às artes, naquele centro de irradiação do pensamento e de tão viva preocupação pelas cousas da ciência, onde se forjava um grande Império, que repercussão teve a idéia de "razão de Estado", locução ambígua que na segunda metade do Século XVI se insinua, no dizer de

dência do Brasil, Porto, 1921, vol. I, Introdução, pg. VII e segs. Lembre-se, a propósito, a afirmação do sábio Pedro Nunes em seu Tratado da Sphera: “descobrimentos de costas: ilinas $\theta$ terras firmes: nam se fezeram indo a acertar: mas partiam os nosso mareantes mui ensinados $e$ providos de estormentos $e$ regras de astrologia e geometria: que sam as cousas de que os Cosmografos ham dandar apercebidos". Sôbre os pressupostos cientificos dos descobrimentos portugueses, V. JoAQUIM BENSAUdE - L'astronomie naulique au Portugal à l'époque des grandes decouvertes, Berna, 1912.

(2) Cf. Montaigne - Essais, L. I, Ch. XXV: “ . en cela Andreas Goveanus, nostre principal, comme en toutes aultres parties de sa charge, feut sans comparaison le plus grand principal de France". 
Rodolfo de MatTeis, "nel vocabolario politico, e poi fulmineamente trabocca nel linguaggio di tutti, ottenendo il facile, universale sucesso che verrá piủ tardi riservato a locuzioni non meno fortunate, quali "contratto sociale", "diritti dell'uomo", "sovranítá popolare" e simili"?

Essa a questão que nos propuzemos, e em cujo estudo chegamos a algumas conclusões, que não haverá mal em enunciar desde logo, quanto mais não seja à guisa de sumário:

1 - O problema da "razão de Estado" foi posto de uma forma nova e mais ampla quando o contraste entre valores políticos e éticos se tornou mais patente e agudo, ao dar-se a ruptura da ordem medieval imantada segundo uma concepção cristã unitária do Universo e da Vida;

2 - "Razão de Estado", não como fato mas como teoria ou desenvolvimento ideológico, é uma categoria histórica, tanto como o conceito de soberania ao qual corresponde e do qual é expressão. particular, marcando um aspécto ou veste do. poder político no processo de sua laicização, ao constituirem-se os Estados Modernos.

3 - Traduzindo tal conceito mutáveis exigências do: poder político na época moderna, não teve uma formulação ecumênica tal como alguns autores quizeram atribuir-lhe; apresenta, por exemplo, características próprias e inconfundíveis na cultura renascentista lusiada e, de maneira geral, na ibérica.

4 - Em Portugal, onde Humanismo e Renascimento se fundiram em um unico processo, enquanto que em outros paizes assinalaram dois

(3) Cf. H problema della "Ragion di Stato" nel Seicento, in "Rivista Internazionale di Filosofia del Diritto", Aprile-Settembre 1949, XXVI - 2-1, pg. 187. 
momentos históricos distintos, a ação e a doutrina política conservam deliberadamente fortes elementos medievais, que dão um cunho especial à sua experiência da razão de Estado, a qual alberga sempre uma tensão ética. que, alhures, só encontramos na época própriamente do $\mathrm{Hu}$ manismo, pois desaparece com a crescente explicação naturalistica dada aos problemas politicos pelos pensadores do Renascimento.

5 - $O$ especial sentido que a idéia de razão de Estado adquire no plano da política exterior, em virtude dos descobrimentos marítimos e da expansão colonial, resulta de circunstâncias históricas peculiares àquele povo, integrado, na éra do Humanismo e do Renascimento, (talvez fosse mais rigoroso dizer: de seu "Renascimento humanístico") em uma comunidade concreta, modelada pelo ideal bipolar da Fé e do Império, tal como se reflete em obras literárias que atiugem sua máxima expressão com GiL Vicente e Lurs de Camões.

6 - Essa fisionomia do Estado lusíada influiu de maneira poderosa no destino do Brasil, não só pela preservação e consolidação de nossa unidade territorial e política, como também pelas tendências que vieram influir poderosamente em nossa maneira de conceber o poder e a lei.

Antes da éra cristã e, mais precisamente, antes de se ter firmado a exigência profunda de uma distinção entre sociedade e Estado, liberdade individual e autoridade política, destino da pessoa e destino da coletividade, poder estatal e poder religioso - distinção que implicava no 
reconhecimento de algo universalmente e éticamente válido por si, fóra e acima da órbita politica do Estado e também antes dessa consciência ética ter sofrido o contraste de inexoráveis resistências brotadas da ação política empenhada na fundação dos Estados Modernos, não se sentiu a necessidade de elaborar-se plenamente, em uma teoria ou em um sistema, o conceito de "razão de Estado", tomada esta locução em seu sentido essencial como subordinação de outros fins aos fins políticos de uma comunidade, na medida exclusiva dos segundos, com fundamento em razões consideradas racionalmente legitimas.

A um primeiro e superficial exame, "razão de Estado" aparece como sendo "cobertura de legitimidade para atos que os governantes consideram úteis ao interesse público, embora em si mesmos devam reputar-se injustificáveis". Nessa acepção, o conceito esconde um plano de legitimação de meios em razão de fins, árbitros dos quais acabam sendo os detentores mesmos da força política. Muitos, por certo, assim o entenderam, convencidos de que a ação política racionalmente objetiva segue seu processo natural, tendo em si mesma a sua legitimidade, na medida em que realiza com êxito uma ordem social segundo as exigências do poder, resultando subordinadas tôdas as esferas de estimativa à consecussão do fim posto como valor supremo.

Não nos parece, que a idéia de "cobertura", ou seja de "intencional disfarce de legitimidade" seja essencial ao conceito de "razão de Estado", cujos significados cambiantes escapam, no entanto, à possibilidade de uma definição.

Poder-se-á talvez afirmar que a idéia de razão de Estado brota da conciência de que existe no âmbito do poder estatal um domínio insuscetível de valoração segundo critérios extranhos às exigências mesmas da ação politica, excluindo-se, assim, a possibilidade de controle 
por qualquer outra instância valorativa. Daí o sentimento de vinculação necessária e exclusiva do poder a seuș fins: todos os fins se integram e se ordenam no processe. de realização plena de uma comunidade social nos limites de sua condicionalidade histórica. Dess'arte, tudo aquilo que possa vir a se contrapor, por qualquer motivo, àquele processo integrativo, embora possa ser estimável em si mesmo como valor singulo, não pode ser destacado do todo, ficando sujeito às pressões inexoráveis da meta deliberadamente proposta. No fundo, são critérios ditados por variáveis conjunturas históricas (unidade nacional, espaço vital, reinvindicações de classe, etc.) assim como outros elementos conaturais ao poder em sux universalidade, que decidem do rumo e da intensidade da ação política, envolvendo em seu processo unitário as atividades dos homens e dos grupos. Só assim se explica a afirmação de MeINEcke, segundo seu prisma especial de historiador, de que "nell'agire secondo la ragione di Stato si manifesta anzi tutto una rigida e ininterrota connessione causale, cosí chiara ed evidente come in nessun altro aspetto della vita storica" (4).

Ora, enquanto o Estado foi concebido como a mais alta expressão da vida ética, não havia própriamente uma "razão de Estado" perante outras esferas axiológicas, porque nenhuma instância se punha que lhe não fosse redutivel.

A razão de Estado na antiguidade clássica pode ter sido, como efetivamente o foi, um fato de que se tinha conciência, mas não chegou a constituir claramente um problema que puzesse a exigência de uma teoria ou de um sistema, como objeto de ciência.

Não cabe aquí indagar da natureza da polis e da urbs com relação ao problema da liberdade individual

(4) Frederico Mernecke - L'idea della ragion di Stalo nella Storia Moderna, trad. de D. Scolari, Vallecchi Editore, 1942, vol. I, pg. 8. 
e a possibilidade de uma ordem de valores suscetivel de pôr-se perante a que era consubstanciada no organismo do Estado-cidade, pois tal indagação nos levaria muito longe dos propósitos desta comunicação.

Quer se admita, porém, a politicidade total da vida ética no mundo dos clássicos, com redução absoluta de todos os fins aos da comunidade politico-religiosa, consoante e conhecida tese de Benjamin Constant e de Fustel de Coulanges (donde a sustentada identificação de liberdade individual e liberdade coletiva, de individualidade e ci. dadanía); quer se reconheça a existência de um individualismo fundamental também no mundo greco-romano, como sustentaram Hauriou e GLotz; quer ainda se demonstre que ambos êsses pontos de vistas refletem aspéctos parciais de um problema bem mais complexo, insuscetível de solução segundo categorias peculiares à moderna concepção do Direito e do Estado (5) o certo é que o Estado Urbano representou para gregos e romanos a instância última de aferição dos comportamentos e dos interesses.

Muito claramente CICERo nos revela a força espiritual do Estado-cidade, nesta incisiva passagem do "De Republica": "Neque enim hac nos patria lege genuit, aut educavit, ut nulla quasi alimenta exspectaret a nobis, ac tantummodo nostris ipsa commodis serviens, tutum perfugium otio nostro suppeditaret, et tranquillum ad quietem locum: sed ut plurimas et maximas nostri animi, ingenii, consilii partes ipsa sibi ad utilitatem suam pigneraretur; tantumque nobis in nostrum privatum usum, quantum ipsi superesse posset, remitteret."

Concebida, assim, a absoluta preeminência éíca da comunidade politica, era desnecessário desenvolver uma teoria

(5) Sôbre tal argumento, v. o nosso estudo Liberdade Antiga e Liberdade Moderna na "Revista da Universidade de São Paulo", vol. I, 1950.

(6) Cicero, De Republica, I, IV - 14. 
da razão de Estado capaz de justificar a exclusiva vinculação do poder a seus fins, de sorte que nos parece possível afirmar, com apôio em certas passagens de Aristóteles, de Cícero, Tito Lívio, Tácito, ter havido no mundo clássico apenas "ricchi tentativi svolti a formulare" aquela concepção (7).

Não bastará lembrar que êste ou aquele político ou escritor sentiu a necessidade de justificar um ato invocando a utilidade ou o interesse do Estado. Teoria da Razão de Estado é mais do que isso: é a teoria da justificação, ou, por outras palavras, a justificação da justificação do poder pelos aduzidos fins do Estado. Enquanto se disse: Roma locuta, tollitur quaestio, não houve teoria da razão de Estado, porque esta reside exatamente na quaestio posta como inevitável.

No mundo clássico, em síntese, não surgiu ou não se aperfeiçoou uma doutrina da razão de Estado, mesmo quando interesses de Estado se invocaram, porque tal invocação por si mesma tornava qualquer justificação desnecessária.

(7) Nesse sentido, cf. Meinecke - op. cit., vol. I, pg. 39 e segs. Os teorizadores da razão de Estado no século XVII foram incansáveis na procura de precedentes clássicos para as próprias doutrinas. Com isso o conceito se alargou tanto até se confundir com o de Politica. Na realidade, como observa De Matteis, "a seconda dell'idea che si ha di Ragion di Stato, si ritroverá l'embrione antico, che pertanto non sarà sempre il medesimo. Cosí, chi interpreterá la Ragion di Stato come semplice Arte di Governo, troverá facilmente in Platone l'anticipo in tal senso. E chi la intenderá come legge non scritta e universale, si orientará verso Aristotele. Chi, infine, la riterrá una violenta iniziativa del Principe, ai fini della pubblica utilitá, additerá Tacito; e via dicenıdo. Nella segnalazione dei precedenti dottrinali v'é già, insomma, implicita la personale visuale del singolo studioso" (loc. cit., pg. 210). 
$O$ Cristianismo veio atingir em cheio a essência monista do Estado antigo, distinguindo o Império da Igreja ("Dai a Cesar o que é de Cesar, e a Deus o que é de Deus") e proclamando a dignidade universal do homem, irredutível à dignidade do "cidadão". Na parábola do bom samaritano, para não invocar senão um exemplo, resplende esta força ética e universal da idéia do "próximo", da "humanitas" dignificada em si mesma, desprendida de quaisquer vinculos de cidadania ou de nacionalidade.

Tinha início, em verdade, uma revolução profunda, que, segundo expressão feliz de Oтto Schilling, consistia sobretudo em uma "cultura da personalidade". $\mathrm{O}$ homem deixava de valer apenas como "cidadão", para passar a valer como homem, como pessoa, adquirindo um cunho novo e mais profundo a concepção de "humanitas" já afirmada na doutrina estóica.

E paradoxal, mas verdadeira, a afirmação feita por um historiador católico de que foi a apoliticidade, ou seja, a falta de preocupação política, que fez brotar do Cristianismo uma grande revolução no plano político (8).

Sendo apolítico, o Cristianismo implicou necessariamente na quebra do caráter religioso do Estado antigo, na distinção entre a esfera religiosa e a política, instituindo uma ordem moral de caráter universal, perante a qual também o Estado devia inclinar-se.

Ora, na Idade Média, enquanto o reconhecimento daquela ordem sobrenatural se manteve uma realidade viva, a razão de Estado poude ser um fato, mas não chegou a converter-se em problema, para o qual se sen-

(8) E. MAGNiN - L'état, conception payenne, conception chrétienne, 1931, pg. 21. 
tisse a imperiosa necessidade de dar uma solução racional.

Admitir uma ordem superior transcendente como instância à qual o Estado deva sujeitar-se na totalidade de suas manifestações é excluir a possibilidade de uma justificação do Estado posto como "razão" exclusiva do agir. 0 que na Antiguidade era desnecessário, na Idade Média torna-se de certo modo impossível.

Foi ao mundo moderno que tocou viver plenamente o drama da justificação do Estado em si mesmo, drama êste que pressupõe sempre uma outra instância além do Estado, mas perante a qual se julgam poder aduzir razões de Estado de validade intrínseca e bastantes por si mesmas.

\section{IV}

O aparecimento dos Estados Modernos marca uma busca angustiosa de explicação do poder político no âmbito de sua própria natureza, nas razões de seu intrínseco desenvolvimento, sempre admitindo, expressa ou implicitamente, uma instância axiológica diversa, segundo cujos prismas os atos ou os acontecimentos poderiam ou deveriam ser aferidos.

O contraste Igreja-Império, não obstante as violências de seus choques, transcorre todo no seio de uma comum concepção do universo e da vida, na graduação de uma única tábua de valores em que ambos os contendentes apoiavam suas reivindicações. Era um conflito que não transpunha os horizontes de uma ordem humana explicável segundo valores transcendentes.

O Renascimento assinala ${ }_{5}$ ao contrário, no plano da vida social, uma inquietação criadora que procura resolver os problemas do homem em sociedade descendo às raizes dos impulsos associativos, segundo "quella riduzione ai principii che é la parola innovatrice del rinasci- 
mento per tutio ció che riguarda l'uomo e la sua vita associata". (9)

O mesmo acontece na consideração do poder politico, analisado na sua estrutura e nas suas razões, assim como no seu projetar-se no cenário histórico. A idéia de soberania, como poder que não recebe de fóra a sua legitimidade, mas que se justifica a si mesma pelo simples fato de ser, é uma afirmação violenta da nova estrutura cultural do Ocidente.

O conceito de "razão de Estado" corresponde ao de soberania, marcando ambos a forma do poder tornada polêmica e conflitante na condicionalidade histórica dò mundo moderno, na obra de autores que, obedecendo ao ritmo do tempo, procuram inspiração nos modelos politicos da antiguidade clássica.

Tal retorno às concepções antigas, neste como em outros campos da experiência humanista, não podia verificar-se, porém, fazendo-se tabula rasa da experiência do Cristianismo, maximé por terem sido Humanismo e Renascimento, notadamente o primeiro, ao con trário do que durante longo tempo se supôs, movimentos marcados por profunda inquietação religiosa e de pon. deráveis elementos medievais. (10)

Explica-se, pois, a complexidade do pensamento da época, reelaborando os temas da Política e da Jurisprudência clássicas, visando superar a tensão viva que se

(9) N. Abbagnano - Storia della Filosofia, U. T. E. T., vol. II, pg. 28 .

(10) Concordanos plenamente com DE RugGiero quanto ì força de motivos medievais na cultura renascentista: "In mezzo alle differenze confessionali, alle esperienze politiche divergenti, ai conflitti degli indirizzi scientifici e filosofici, sopravvive l'antico spirito unitario e lentamente si transforma per adeguarsi alle nuove esigenze: si fa piú cedevole ed elastico, perché piú mobile e snodato é il contenuto da accogliere; meno visibile forse, ma nondimeno presente" - Storia della Filosofia, Parte Terza, Rinascimento, 
estabelecida entre Individuo e Estado, entre consciência ética e consciência política, na procura de uma possível conciliação entre a idéia antiga de imperium e a idéia cristã de pessoa; era como se dois mundos forcejassem para se comporem em uma unidade nova. Ora, é nessa conjuntura histórica que surge e se desenvolve a "teoria da razão de Estado", marcando um encontro e um conflito de civilizações e de culturas.

A nosso ver, o sentido geral do Humanismo, pela consciência da dignidade das ciências do homem e de sua irredutibilidade ou subordinação às ciências da ordem física, não chega a pactuar com a tese da "vinculação inesorável do poder às razões imanentes a seu processo", tese esta que envolvia uma cosmovisão naturalistica só afirmada em certas tendências marcantes da problemática do Renascimento.

De certa forma, poder-se-ia dizer que se colocaram à margem ou além do drama essencial do Humanismo aqueles pensadores que cortaram pela raiz os fios da referida tensão espiritual, seja optando por uma solução anti-cristã ou a-cristã de extrema politicidade; seja, pelo reconhecimento pacífico de uma ordem sobrenatural em que deveriam se inserir todos os momentos da ação política.

Eis, talvez, um dos motivos pelos quais, se a teoria da razão de Estado se constitui e se desenvolve quando o homem se torna perplexo ante a perda da unidade espiritual que caracterizara a Idade Média, ela se revela tanto mais poderosa e crua quanto mais marcante a desesperança na salvação dos homens graças aos valores morais do Cristianismo, assumindo formas radicais em pleno processo renascentista

Riforma e Ciontroriforma, Bari, 1947, 4.a ed., vol. I, pg. 4. Apreciando. a matéria sob um prisma filosófico-político, pareceu-nos plausível. ver na Idade Média a Idade Inicial, em cujo sistema aprofundam raizes certas ideologias do Quatrocento (icf. Miguel ReAle — Formação da Politica Burguesa, São Paulo, 1934, 1.a Parte, A Idade InicialQ 
segundo a linha do naturalismo que se continha no sistema de sua tendência e que viria a ser a dominante nar apreciação dos problemas do Estado.

Em Machiavelli, pior exemplo, a razão de Estado é a única via de saida para o homem moderno perdido na selva de seus impulsos naturais.

Tudo se reduz ao Principe e por êle se mede. Tudo se reclama do Príncipe porque se julga nada ser possivel esperar do Cristão. Em contraposição, como que nos oferecendo a contra face do mesmo fenômeno, a astúcia do Principe tende a ser contrabalançada pela astúcia do súdito, escogitando meios e modos para furtar-se a seus comandos, através de todo um jogo casuístico, uma de cujas formulações a encontramos na nova apresentação da doutrina das "leges mere poenales", em virtude da quai se esvasiava a obediência de seu conteúdo ético, como de conteúdo ético se esvaziara o princípio do poder. (11)

Esquematizados os elementos necessários a uma configuração geral do problema, podemos verificar como a

(11) “C'est, en effet, au moment ou, sous l'influence du droit romain, les légistes détachaient le droit positif de son fondement ideal - l'Ordre, la Justice, — pour faire dériver toute son autorité de la volonté du prince, que la theorie des lois purement pénales s'évada le plus hardiment des limites très resserrées où l'enfermait la Somme da saint Thomas et prit tout son essor. Le "légisme" de la Renaissance e provoquè le "casuisme" de Suarez: les deux attitudes se tiennent comme pile et face. On cherchait l'antidote dans le poison; la loi puremente pènale, d'après l'interprétation commune, c'est l'ordonnance à la violation de laquelle le prince est censé n'avoir pas eu l'intention d'attacher d'autre conséquence que l'assujettissement à l'amende ou à la prison: quidquid principi placuit...; il ne faut pas être plus royaliste que le roi!" Georges Renard - La théorie des Leges mere poenales, in «Mélanges Maurice Hauriou", Paris, 1929, pg. 639. 
idéia de razão de Estado operou no pensamento português dos séculos XV e XVI, refletindo-se na obra de seus cronistas, poetas políticos e juristas. A primeira observação que nos cabe fazer é quanto à precoce formação do Estado português sôbre uma base nacional, com uma estrutura juridico-política unitária, que lhe possibilitou superar em pouco tempo os quadros da política medieval.

Podemos concordar com Oliverra Martins quando assevera que a partir de 1385, com a subida ao trono do rei D. João I, termina a Idade Média portuguesa, não só porque é um poderoso sentimento de brio nacional que condiciona o advento da nova monarquia, em luta contra Castela, como também pela própria configuração do poder, para o qual desde logo se propõe uma justificação nova, de todo alheia à idéia do Sacro Romano Império, combinando-se a origem popular do poder com o primado. da autoridade, a qual, uma vez conferida pelo povo, passaria tôda ao monarca. (12)

D. JoÃo I teve um admiravel teorizador de suas prerrogativas reais na figura de um jurisconsulto subtil, formado nos ensinamentos de Bolonha, o famoso JoÃo DAS Regras, em cujas argumentações a invocação do primado pontifício perdia o cunho de sacralidade, para adquirir uma expressão pragmático-política em função da causa da independência lusa.

É aquele, porem, ainda um príncipe de formação medieval, marcando sua atividade criadora uma transição para novas formas de conceber-se o poder de Império.

É com êle que se estrutura o novo Estado, como uma obra de arte, tendo como base uma concepção nacio-

(12) Cf. J. P. Oliverra Martins - Histórid de Portugal, 4.3 ed., Lisboa, 1886 , t. 1 , pyg. 160. E de notar-se que a idéia de Sacro Romano Império, tão decisiva para os destinos da Espanha, não medrau no meio lusitano. Cf. do mesmo Oliverra Martins - Os

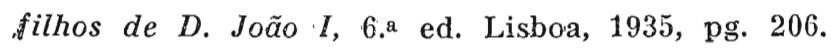


nalista, singular em uma época na qual ainda não brotara na Europa a idéia de nacionalidade, suscitada e fortalecida em Portugal pelo duplo contraste com os reis de Castela e os sarracenos. Foi a luta contra êstes que deu origem a um amálgama de nacionalismo e catolicidade, de que iria resultar mais tarde uma formulação original da razão de Estado.

Maravilhoso destino o desse rei português que durante quasi cincoenta anos (1385-1433) consolidou o seu Estado, deixando uma prole magnifica ("Inclita geração, altos Infantes", dirá CAMõEs nos "Lusiadas") cujo estudo oferece tantas razões de encantamento para quem procura compreender facetas imprevistas da cultura humanística em um ponto extremo do mundo europeu, onde portugueses, castelhanos e sarracenos defendiam seus direitos e interesses, conflitando-se em armas e modos de viver.

Retratam os filhos de D. JoÃo I um quadro dos mais empolgantes, assinalando cada um deles, de certa forma, as diferentes tendências que atuavam no bojo dos acontecimentos, no contraste entre velhos hábitos, inveteradas tradições e avassaladoras exigências postas pela redescoberta do homem e do cosmos. Destaquemos apenas quatro nomes da grande galeria. Teremos a impressão de que através deles o espírito do tempo veio se revelando misteriosamente, desde o senhor feudal, trancado em suas pretencões baronais, até ao estadista sequioso de desvendar os mistérios do planeta em um desejo incontido de saber e de posse. É com a "Inclita Geração" que começam a brilhar na cultura lusa os primeiros alvores do Renascimento. (13)

O primeiro dos filhos do Mestre de Avis foi um bastardo, D. Afonso, I Duque de Bragança, que personi-

(13) V. Hernani Cidade - Lições de cultura e literatura portuguesas, Coimbra, 2. ${ }^{\mathrm{a}}$ ed., 1943, pg. 65 e segs. 
ficou a tradição feudal, lutando contra as prerrogativas da coroa, tradição que seus descendentes conservaram durante meio século, até serem definitivamente esmagados pela política férrea de D. João II, (1481-1495) a maispoderosa encarnação da "razão de Estado" na história portuguesa.

O segundo filho de D. Joño I foi rei sob o nome de D. Duarte. Espírito ilustrado e inquieto, tem sido alvo das interpretações mais desencontradas. Sua obra literária, de fundamental importârıcia nas letras lusiadas, revela-nos um espírito em que elementos medievais e humanisticos se acasalam, mais do que se conflitam, com marcante predominância dos primeiros. Daí ter sido apontado, ora como um "homem estruturalmente medieval", ora como um precursor da dúvida cartesiana, quando a verdade está na coexistência de fatores novos e tradicionais em uma justaposição que, à primeira vista, parece confusa ou contraditória.

No quadro da sociedade portuguesa representa, contudo, algo de novo, não só pelo amor ao estudo de autores medievais e antigos, como também pelo valor dado à própria experiência pessoal. (14)

(14) Quanto ao pretenso "pré-cartesianismo" de D. Duarte, V. M. Ronrigues LAPA, Lições de Literatura Portuguesa, Época Medieval, Lisboa, 1934, pg. 266. Joaquim de CARvalho, sem avançar àıueles extremos, põe no devido idestaque a penetração crítica de D. Duarte na apreensão da natureza das paixões e na análise do. conhecimento, ao surpreender com subtileza a essência dos sentimentos, em uma obra que conserva "o valor, quasi modelar, de atualidade, porque trocou a autoridade livresca pela observação e vivência pessoal". (Cf. Leal Conselheiro. Ed. Joseph Piel, 1942, pg. XIX). Sem negar totalmente o ponto de vista da "maior parte dos historiadores" que consideram as transformações hîstórico-sociais do reinado de D. João I o despertar da Renascença portuguesa, entende, no entanto, Antonio Soares Amora que, "se $\dot{e}$ verdade que se naqueles acontecimentos estão as raizes das. 
O seu livro intitulado "Leal Conselheiro", escrito por volta de 1437 , é obra de especial relevo para estas notas de estudo, pois contém passagens que revelam a consciência que possuia "el rey" das tentações do poder, aberto a possíveis conflitos entre prudência e justiça, enquanto que a prudência verdadeira - à qual devem subordinar-se todos os homens, mas especialmente os soberanos - não pode se confundir com a astúcia, devendo permanecer sempre nos limites da justiça.

A tensão ética, a que acima nos referimos, como essencial à linha humanística, mostra-se bem viva no Leal Conselheiro, ao qual já se quiz atribuir, nesse ponto, os méritos de uma resposta antecipada às teses inflexiveis

tônicas da vida quinhentista ( $O$ absolutismo e o imperialismo oceânico) - também é verdade, e verdade inconcussa, que os ideais que conduziam o espírito de $D$. João e de seus filhos são genuinamente medievais. D. Duarte não é um homem da Renascença, nem mesmo da Pré-renascença. É um homem típico, é a expressão acabada da alta Idade Média, do outono da Idade Média, época que na magistral interpretação de Huizinga se caracteriza pela definição final do estilo de cultura do mundo medievo" (SoAres Amora - El-Rei Dom Duarte e o "Leal Conselheiro", São Paulo, 1948, pg. 213). Essa afirmação prende-se talvez a uma visão excessivamente esquemática do Humanismo, em cujo processo continuaram operando relevantes motivos medievais.

Variada e rica era, para a época e o meio, a bibliotéca do rei D. Duarte. Catalogam-se 88 obras, em latim e português, destacando-se livros de Aristóteles, Cícero, Julio Cesar, Sêneca, Santo Agostinho, Avicena, Bártolo, Marco Polo, assim como estudos de história, montaria, agricultura, polftica, astrologia, lógica e poesia, sem contar os romances do ciclo arturiano. Cf. Leal Conselheiro, o qual fez Dom Eduarte, rey de Portugal e do Algarve e Senhor de Cepta, edição crítica organizada por Joseph M. Piel, Lisboa, 1942, pg. 14 e segs. Essa Bibliotéca refletia de certa forma, a atitude de seu espírito que não pode ser todo situado na "Weltanschaung" medieval. 
de Machiavelu, obedientè às razões "efetuais" das cousas. (15)

Essa conciência viva do justo não lhe impediu, no entanto, de compreender as razões da preservação e da "grandeza" da monarquia e de sua fazenda, como o demonstrou com a promulgação da chamada Lei Mental. Como seu pai houvera sido obrigado a exceder-se em liberalidades, galardoando serviços de fidalgos com bens da coroa, declarou que tôdas as doações haviam sido feitas com a idéia ou a intenção de reverterem novamente os bens ao monarca na falta de herdeiro varão. O jurista subtíl, JoÃo dAs Regras, mestre em razão de Estado e inspirado no Direito Justinianeu, escogitara uma solução "prudente", com que aquietava a consciência escrupulosa do rei, a quem, aliás, Ourveira Martins chega a atribuir a iniciativa da Lei, ainda quando principe herdeiro.

A doutrina pressuposta na Lei Mental não se enquadra mais na estrutura da concepção política medieval, nem se harmoniza com os principais elementos ideais do Leal Conselheiro, revelando, outrossim, o advento e a natureza de uma outra força que iria modelar a imagem do Estado: a Jurisprudência romanística, pelo apôio relevante dos legistas aos direitos dos reis, assim como aos interesses do povo, notadamente da burguesia mercantil ávida de enriquecer-se nos empreendimentos ultramarinos.

Por outro lado, o problema politico colora-se de outras tintas quando o rei passa a considerar a questão dos mouros e judeus, reputando licita a guerra contra os infiéis, não para obrigá-los à fé, mas para garantir a liberdade de sua propagação (16). Já se afirmava, assim, a consciência doutrinária da identificação da razão do Império com a razão da Fé, de que cuidaremos logo mais.

(15) Cf. Leal Conselheiro, ed. cit., Capits. LII e LXXX. Nesse sentido, F. E. DE TeJada Spinola - Las Doctrinas polfticas en Portugal, 1942, pg. 93.

(16) Cif. Leal Conselheiro, cit., Cap. XVII 
E' no terceiro dos filhos de D. João I, D. Pedro, Duque de Coimbra, que se acentuam, no entanto, os traços humanísticos. Homem culto e viajado, a quem o jurisconsulto florentino Tommaso Salverti dedicou uma de. suas obras, foi um apaixonado de coisas antigas e novas. Tradutor, entre outros trabalhos, do De Officis de Cicero. e de parte do livro de Marco Polo, foi, de certa forma, o introdutor da cultura nova no mundo lusiada: foi êle quem trouxe de Veneza, para o irmão D. Henrique, o navegador, um exemplar da obra do explorador genovês, os mapas de Valseca, os trabalhos de Jorge P'urbach, etc., cuidando sempre de contentar os pendores literários do primogênito $D$. Duarte e a sêde de conhecimentos positivos que animava o irmão menor, o Infante de Sagres, a quem estava reservado tão radioso destino na história dos conhecimentos e descobrimentos náuticos.

Legou-nos o infante D. PEDro uma obra fundamental A Virtuosa Benfeitoria, tratado político-moral calcado no De Beneficiis de SÊnECA, mas com amplos desenvolvimentos atribuiveis em parte à colaboração de Frei João Verba.

O conceito que $D$. Pedro nos dá de benfeitoria nãoé estritamente jurídico, enquadrado no sistema políticofeudal, mas essencialmente ético, consoante acertada interpretação de Tejada Spínola, de sorte que a comunidade política se constitui como "uma gigantesca síntese de benefícios quotidıanamente acrescentados", resultando a convivência de laços de amor e de gratidão, de lealdade e de respeito mútuos como condição de senhorio. (17)

(17) Tejada Sprnola - op. cit., 115 e segs. Sôbre a Virtuosa Benfeitoria, cuja edição crítica de 1940 foi cuidadosamente revista por Joaquim Costa, merecem destaque ainda os estudos. 
Com razão observa MerÊA, o insígne analista da cultura jurídica portuguesa, que há em $A$ Virtuosa BenSeitoria o pensamento correlato de que uma coisa se exige sempre, senão como fundamento, ao menos como condição do poder: êsse requisito é o voluntário consentimento do povo. Declara, aliás, D. Duarte expressamente que . nom usara de crueldade o principe com aquellos que pera sua defensom lhe derom a spada”. (18)

Não se pode, porém, olvidar que devemos ao zelo de D. Pedro, quando Regente de Portugal, durante a menoridade de seu sobrinho D. Afonso, a promulgação daquele notável monumento jurídico que recebeu o nome de "Ordenações Afonsinas". Ora, nestas encontramos consagrada a doutrina de que " o rei tem principalmente o regimento da mão de Deus e assim como seu vigário e lugarrenente é absoluto de tôda a lei humana", (L. II, t. 24) sendo impossível não ver refletido aí o pensamento do autor de A Virtuosa Benfeitoria, cioso das prerrogativas reais, embora consciente da lealdade e da prudência como rirtudes inerentes a elas.

de Mêrea, abaixo citados, os de Joaquim de Carvalho - Desenvolvimento da Filosofia em Portugal durante a Idade Média, Coimibra, 1927, sem esquecermos as páginas sempre vivas de Oliveira Martins em os filhos de D. João $I$. A respeito de D. Pedro declara acertadamente Fidelino de Figueiredo ser êle um precursor da cultura clássica, pois "recebera, por estudo e leitura, a profunda influência das letras e da filosofia clássica e a incorporara em seu espírito tão intimamente que o mecanismo de sua inteligência faz-se de modo diferente do dum pensador caracteristicamente medieval". F. Figuerredo - História da Literatura Clássica, 1. ${ }^{2}$ época, $3 .^{a}$ edição. São Paulo, 1936, pg. 42 e segs.

(18) V. Manuel Paulo Merêa - Estudos de História do Direito, Coimibra, 1923, pg. 207. Cs. A Virtuosa Benfeitoria, ed. cit., pgs. 105 e segs. 


\section{VII}

Resta-nos agora falar do quarto dos filhos de D. João 1, o Infante D. HenriQue, cuja figura já se antecipa como am heróe da Renascença, perdido no seu sonho imperial, tudo dobrando às necessidades inexoráveis dêsse desidesatum.

Ele marca, na maravilhosa progênie de D. João e de D. Filipa de Alencastre, um ponto ideal projetado para o futuro, como o promontório de Sagres onde se recolhia para forjar seu destino ao lado de cosmógrafos, cartógrafos e marujos, na angustia de desvendar os mistérios de mares "nunca dantes navegados".

Dêsse sonho brotaria um valor novo, alargando os horizontes da política lusíada e marcando uma compreensão singular e moderna da razão de Estado, à qual tudo seria necessário sujeitar, como D. Henrique mesmo deu exemplo trágico, ao entregar aos sarracenos, na desgraçada expedição de Tanger, o pobre irmão D. Fernando, como refém a garantia da devolução de Ceuta, a qual - êle hem o sabia - jamais seria devolvida...

Mas essa já é uma outra face ou momento do problema que estamos analisando: è a razão de Estado no plano da política externa, na expansão do poder, no projetar-se do imperialismo, a força que iria mudar a fisionomia do mundo.

Por ora, cabe-nos fazer uma referências, embora sumária, àquele que viria completar o processo interno de fundação do Estado, pressuposto e condição do pleno desenvolvimento das conquistas imperiais. Referimo-nos ao já lembrado D. Joño II em cujo breve reinado de catorze anos foi consolidada a supremacia da autoridade real, completando-se a obra de seu bisavô, primeiro do niesmo nome.

D. JoÃo II não era homem de letras como seus avós D. Duarte e D. Pedro, cujos filhos Afonso e Isabel se 
uniram em matrimônio, mas um homem de ação, no mais alto sentido da palavra. Machiavelli, se porventura houvesse tido pleno conhecimento de sua vida e de sua obra, ter-se-ia lembrado de suas decisões prontas e inflexiveis ao redigir as páginas de II Principe quasi três lustros após a morte do grande rei, cuja fama encheu o século, apontado como o Principe Ferfeito (19).

Não foi, porém, maquiavélico no sentido inautêntico da expressão, ou seja, para servir a interesses despóticos: dominou-o sempre o sentimento de seus deveres para com a comunidade, o mais firme respeito pelos imperativos da lei: "Pola ley e pola grey" foi a sua divisa, e a ela se manteve sempre fiel. (20)

A fonte primordial de conhecimento da vida do monarca é a Chronica de El-Rei D. João II, de GARcia dE REzENDE, na qual surge de corpo inteiro a figura do Príncipe

(19) Da imensa fama que D. Jō̃o II lograra en tôda a Europa é testemunho a longa carta que Angelo Poliziano lhe escreveu, tomado de entusiasmo, carta essa que assim começa: "Quanquam nec fortuna mea, nec eruditio, nec ulla commino virtus ciusmodi est, ut licitum mihi putem schribere ad te rex invicte, tanta me tamen dignitatis, splendoris, gloriaeque tude, tantaque laudum tuarum iam per omnium or a volilantium perculit admiratio, ut sponte sua calamus ipse meas exhibere tibi litteras, testari animum, significare voluntatem, gratias agere denique totius setatis nostrae nomine gestiat. Quae nunc virtutum tuarum pene coelestium beneficio iam cum vetustis soeculis, iamque cum omni fortiter audet antiquitate contendere". Em resposta, disse o rei portur guês, entre outras coisas, o seguinte: "Et ut tibi brevibus ad propositum respondeamus, scias nos tui oficci, \& pii laboris, quent in nostrae mortalitatis redemptionem tam crebro polliceris esse admodum gratos, idque amplectimur, vehementerque laudamus". (O texto latino é reproduzido de Fidelino de Figueiredo - $A$ Épica Portuguesa no Século XVI - São Paulo, 1950, pgs. 93 e 97).

(20) Cf. Afranio Peixoto - o Principe Perfeito, Lisboa, 1942, pgs. 40 e segs. 
entregue à luta contra poderosos vassalos que eram contra "estado, honra e segurança d'El-Rei".

O episódio que nos relata o cronista do julgamento do III Duque de Bragança, neto daquele a que já nos referimos, é bem sintomático da psicologia da época: inflexível nos desígnios de salvar o Estado, pondo termo ì prepotência e à felonia dos barões, o rei, à medida que os juízes iam proferindo seus votos de condenação à morte, era tomado de uma emoção profunda e, em pleno conselho, foi visto a "chorar muítas lágrimas, e dizer palavras de compaixão e sentimento" (21).

Nesse episódio, incompreensível talvez là psicologia de nossos dias, parece-nos viva aquela tensão entre valores do social e do humano que, pela presença do ideal cristão da vida e da dignidade do homem, é uma constante da cultura humanística. À luz crua da razão de Estado não teriam sentido aquelas lágrimas de cristão"como homem mais cheio de piedade, que de ira nem rigor, acusando a Deus seus pecados próprios" (22) se é que, na complexa problematicidade da razão de Estado, não se esconde a duplicidade do estadista e do homem, o segundo afogando em lágrimas sinceras as frias deliberações do primeiro.

Quando, em verdade, o poder o exigia, D. João II não vacilava, como não vacilou quando se convenceu da necessidade de eliminar seu cunhado, o Duque de Viseu, fazendo-o a punhaladas, com suas próprias mãos, por estar conspirando, como o outro Duque, contra "seu estado e segurança". Fê-lo calculadamente e friamente, sem reunir conselho, na presença de testemunhas, "que com seus ditos aprovaram e justificaram a morte do duque".

Tão consciente estava de suas razões que delas deu conhecimento imediato à sogra: "lhe mandou logo notifi-

(21) Garcia de Rezende, op. cit., capitulos XLV - XlVI.

(22) loc. cit. 
car a morte do filho, e mostrar as causas e culpas do caso, para ver as razões que tivera de o matar" (23).

Merece ainda lembrança um episódio cujo alto significado não será demais encarecer: certa vez, estava o Rei com os desembargadores julgando um feito, e, ao chegar o momento de se tomarem os votos, um deles, Nuno Gonçalves, se levantou, declarando que, tendo o Rei interesse na causa, era mister que se retirasse a-fim de que o julgamento pudesse se realizar com inteira liberdade.

Indignou-se o Rei, estranhando que isto lhe dissessem:

"Isto me haveis vós de dizer? Como em mim se entende isso, se eu sou a justiça mesma, como hei de ser parte?"

Irredutíveis, no entanto, se mantiveram os juizes, e o Rei, após passear um pouco pela casa sem falar nada, acabou por agradecer a Nuno Gonçalves, pela sua firmesa e honestidade, retirando-se para que julgassem segundo suas consciências... (24)

Eis aí, na sua singeleza, um fato de crônica de valor universal: a identificação que mais tarde iria ser feita por HobBes entre soberania e justiça explode, por antecipação, na fala do maior dos reis da segunda metade do século $\mathrm{XV}$, mas recua ante a viva consciência cristã do justo revelada por magistrados exemplares.

\section{VIII}

Portugal, fortalecido internamente pela unificação do poder real e a entusiasta colaboração da burguezia mercantil, de cujos interesses conjugados os legistas haviam sido intérpretes atilados, lançou-se com entusiasmo à con-

(23) Iv. Garcia de Rezende, op. cit, Caps. LIII e LIV.

(24) op. cit., Cap. XCVII. 
quista de novas terras, com poderosa consciência de seu destino.

Enquanto se tratava de retomar aos mouros o chão pátrio, não havia necessidade de justificar o empreendimento, mas, desde a conquista de Ceuta, ou seja, desde os primeiros passos da dinastia de Avis, cumpria legitimar a invasão do continente africano. O problema da guerra justa punha-se, assim, de maneira nitida, imperiosa. (25).

Assistimos, então, à formação de uma consciência imperial e, ao mesmo tempo, religiosa, alargando-se a idéia das Cruzadas, que os europeus haviam sempre circunscrito à retomada dos santos lugares. No sentido "missioneiro" das cruzadas inseria-se a luta contra os infiéis, não para lhes impôr a fé, pela astúcia e pela violência, mas para assegurar sua livre propagação, confiando-se no êxito da revelação racional da verdade, como dizia Dom Duarte nas pegadas de Raimundo Lulro.

De longa data o fino senso pragmático da gente lusa sentira a força de uma identificação entre $F e ́$ e Império, patriotismo e catolicidade, na particularidade de suas circunstâncias histórico-geograficas, mantenḋo, na defesa dos interesses da comunidade, uma política de sagaciaade

(25) O problema do "bellum justum" liga-se estreitamente ao de Razão de Estado. "In its purity, the doctrine is wholly an ethical one. There must be an objectively just cause of war, waged by the authority of the prince, and he must be inspired by the "recta intentio". Even the prince who has a just cause of war, can make an unjust war, if he acts from wrong motives, such as. territorial aggrandizement or elimination of the enemy as a competitor in the future. And, if all these are fulfilled, the war can still cease to be just, if the prince imposes an "injusta pax" escreve o internacionalista Josef I. KUNZ - Bellum justum and bellum legale in "The American Journal of International Law", Júly 1951 - pg. 528 . 
e firmeza, devotamento e sobranceria com relação ao poder pontifício.

Já em 1345, o rei D. Afonso IV escrevera ao papa Clemente VI, protestando respeitosamente contra a entrega das ilhas Afortunadas (as Canárias) ao príncipe D. Luís, "para extirpar as estéreis varas da infidelidade", "para plantar a vinha dilecta de Deus", por entender que devia ter sido convidado com preferência a qualquer outro, em virtude de sua expedição anterior às referidas ilhas. Excusava-se, por isso, de mandar auxílios àquela empresa, não obstante seus altos desígnios, prontificandn-se apenas a permitir que de seus reinos e terras o Príncipe retirasse "à sua custa e por justos preços, navios, gentes de armas, e outras cousas para o dito intento". Invocava, para justificar a recusa, as necessidades e premências de seu povo, contraidas "pela defesa e dilatação da fé católica", lançando a incisiva pergunta: "Acaso a caridade bem entendida não deve começar por nós?" (26)

Essa tendência a não arrostar sacrifícios pelo puro ideal da Fé, mas sim a servi-lo apaixonadamente enquanto e desde que integrado na existência da comunidade, será uma constante da cultura portuguesa renascentista. Não haverá um despreendimento cavalheiresco de autêntico cruzado, a não ser em certos momentos em que ressurge, como ra figura de D. Sebastião, a mola atávica do cavaleiro medievo.

Longe de nós a idéia de reduzir a consciência das descobertas a um puro fáto econômico, transformando os apelos da Fé em mero embuste ou disfarce de interesses

(26) v. Carta de el-rei D. Afonso IV ao papa Clemente IV, de 12 de fevereiro de 1345, inserta nos Anais Eclesiásticos de Baronio e reproduzida, em fac-simile, com a tradução de Costa Macedo, in "História da Colonização Fortuguesa no Brasil", cit. pgs. LXIII e segs. 
mercantís. Essa tese simplista que seduz a alguns (27) representa a mutilação de um binômio (Fé-Império) que não pode ser partido sem perda de sua natureza autêntica.

Fé e Império, na alma portuguesa, não são duas for. ças distintas da época renascentista, embora com raizes profundas na cultura medieval, mas uma unidade de sintese indecomponível, dando origem a uma polarização axiológica única, que não tem sido, ao que nos parece, sob tal prisma suficientemente analisada, maximé para a determinação do problema da "razão de Estado" no mundo português quinhentista.

A Fé que animava os lusos não era fingida, inautêntica, nem o resultado de uma substituição inconsciente, mas uma força viva e originária, unida ao impulso patriótico incendido nos embates contra Leão e Castela e os Sarracenos. Foi a luta contra os mouros que paulatinamente fez brotar na consciência coletiva o sentimento de uma coincidência inamovível entre Cristianismo e nacionalidade.

Surgiu, assim, um exemplo magnifico de comunidade concreta. Neste tipo de comunidade os valores do todo não absorvem e aniquilam os valores dos elementos componentes, mas antes se baseiam e se potencializam na afirmação de cada personalidade consciente, assim como cada indivíduo sente-se crescer e projetar-se através das

(27) Assim o julga, por exemplo, Azevedo Amaral quando escreveu: "De balde a reconstituição inverfdica do drama dos descobrimentos tentou crear, em torno dos empreendimentos maritimos a lenda de um impulso religioso para a cristianização das terras remotas e misteriosas. Não foi a fé que os reis de Avis quizeram dilatar, mas o império comercial (sic) que enche os sonhos do Infante D. Henrique com a visão deslumbrante de uma repetição moderna dos periplos púnicos". Ensaios Brasileiros, 2." ed., Rio de Janeiro, pg. 131. É desnecessário dizer que essa é a tese unilateral de quantos se apegam às diretrizes angustas do historiografia marxista. 
realizações comuns. Nessa vida comunitária, que a simples divisão mecânica do trabalho não explica, há uma dedicação de individuo a indivíduo dotada de sentido ético essencial, condicionando o aparecimento de um novo tipo de homem.

No caso em apreço, poderiamos dizer, consoante observação daquele espirito subtil que foi ANTHERo dE QuentaL. que "o velho tipo cavalheiresco, fantasioso e sentimental, empalidece diante desse outro que surge, nobre e digno, quasi severo, o homem do dever, não da sensibilidade, que João de Barros, Ferreira e Miranda vão levantando, e que Camões virá colocar sôbre o sublime pedestal épico. Esse tipo, o verdadeiro tipo português do século XVI, como se revela nos Lusiadas, não é com efeito uma mera invenção do gênio de CAmões: é uma genuina criação nacional, um ideal do sentimento coletivo, que se foi gradualmente formando e depurando, até encontrar no grandepoeta quem lhe désse uma expressão definitiva". (28)

A consciência da comunidade indissoluvelmente ligada ao serviço da pátria e da religião é bem viva nos escritores da época, assim como no espírito dos reinantes, legitimando as expedições à Africa, para as quais se pediam e se obtinham do Pontífice "grandes indulgências e remissões de pecado"

Ésse sentido de "sacralidade" do poder e da ação política nada tinha que ver, porẻm, com a antiga concepção medieval do Sacro Romano Império, a qual, já o dissemos, pouco ou nada representou na história portuguesa.

o imperialismo como cruzada é uma caracteristica do mundo ibérico, e notadamente do português, dele resultando, um ideal comunitário incompatível com as estruturas e hierarquias feudais. Se levarmos em conta o fato de ter o Brasil surgido no processo daquela idea-

(28) ANTHero DE QUENTAL -- Considerações sôbre a Filosofia da História Literária Portuguesa, in "Prosas", Lisboa, Vol. II, pg. 229. 
ção ético-política, compreenderemos o significado e o alcance de termos sido uma Nação a rigor sem feudalismo, originando-se de laços não pessoais as distinções. inevitáveis à vida em sociedade.

\section{IX}

Voltando à linha mestra de nosso tema - cuja natureza nos obriga a uma aderência talvez excessiva às particularidades culturais buscando o pensamento intrínseco às manifestações históricas da atividade espiritual vejamos em quatro autores principais como se revela a teoria da legitimação do Imperialismo.

Na obra de Gil Vicente, a quem se deve o melhor do teatro lusitano, ainda não se afirma a consciência daquela quasi predestinação do reino português para a tarefa dos descobrimentos marítimos que iria ter tão grande difusão na época.

Espirito dotado de larga base realista e crítica, assim como de forte senso de equilibrio e de objetividade deante dos acontecimentos de seu tempo, a ponto de lhe terem sido atribuidas tendências erasmianas, com razão contestadas por Alfredo Pimenta (29), Gil Vicente não se ilude quanto à predestinação de sua gente para o domínio dos mares e a propagação da religião cristã, mas reflete o orgulho da obra realizada sob o binômio da Fé e do Império.

Para não dar senão alguns exemplos, lembremos os. conhecidos versos do "Auto da Fama" em que se exalcam, em contraste com os dos italianos, castelhanos e franceses, os méritos da gente portuguesa:

(29) v. Alfredo Pimenta - O exasmismo de Gil Vicente, èm "Novos Estudos Filosóficos e Críticos", Lisboa, 1935, pg. 244. 
"Fazeis as mesquitas serem desertadas,

Fazeis na Igreja o seu poderio:

Portanto o que póde vos dá domínio,

Que tanto reluzem vossas espadas,

Porque o triunfo do vosso vencer

$\mathrm{E}$ vossas vitorias exalção a fé,

De serdes laureada grande rezão he". (30)

o mesmo tema encontramos em Exortacâa $\dot{u}$ Guerra:

"Africa foi de Christãos,

Mouros vo-la tem roubada.

Capitães, ponde-lh'as mãos,

Que vos vereis mais louçãos

Com famosa nomeada.

O Senhoras Portuguesas,

Gastais pedras preciosas,

Donas, Donzelas, Duquezas,

Que as taes guerras e empresas

São propriamente vossas.

E guerra de devoção,

Por honra de vossa terra

Cometida com razão..."

Eis aí a unidade ideal da Fé e do Império dando a razão da guerra contra os árabes: guerra de devoģão, e guerra conduzida por honra da terra pátria. Os guerreiros que se integram nessa cruzada ganham o reino dos céus, como canta o poeta no Auto da Barca do Inferno, pela boca do Anjo que os acolhe:

"O cavalleiros de Deos,

A vós estou esperando;

Que morrestes pelejando

Por Christo, Senhor dos Ceos.

(30) Obras de Gil Vicente, ed. Mendes dos Remedios, Coimbra, 1912, tomo II, pg. 287. 
Sois livres de todo o mal,

Sanctos por certo sem falha:

Que quem morre em tal batalha

Merece paz eternal".

\section{$\mathbf{X}$}

A idéia de Cruzada torna-se mais precisa e forte na O.jra de JoÃo DE BARRos, o historiador das conquistas lusas na Asia, com razão chamado o Tito Livio das letras portuguesas.

Em João de Barros exalta-se o significado das guerras feitas aos infiéis, como se vê no Panegírico de D. Joño III e nas Decadas, limitando-nos a lembrar as passagens que Hernani Cidade aponta em abono da tese sôbre a geral convicção que a gente portuguesa tinha, no século XVI, de sua predestinação divina para alargar os horizontes da cristandade:

“... foi concedida (a Portugal) a prerrogativa. ganhar os títulos de sua coroa por conquista de infieis. principalmente dos arábios... Parece que, como Deus permitia que êles fossem flagelo e castigo dos pecados de Espanha... assi ordenou que.. por o mesmo modo a poder de ferro, fossem executar natural prerrogativa. . (não só entre mouros), mas ainda entre a gente pérsia, por se converterem à seita destes bárbaros arábios". (31).

Se vem de Deus o cometimento, qual a sua explicação, sendo Portugal um pequeno povo, pequeno para a realização no mundo dos designios do Senhor? E', responde Barros, porque, na Europa, "há nações que impedem o crescimento da católica semente pela cizânia das ambições políticas, confederando com infiéis e heréticos...

(31) Décadas, II, Parte I, pg. 91 (ed. de 1777) conforme trechos destacados por Hernani Cidade, op. cit., pg. 208. 
Há outras, acrescenta êle, que, esquecidas dos deveres de cristãos, perdem-se em dissidências religiosas, fomentando desobediências e heresias.

Portugal, ao contrário, mantem-se uno nos desígnios de Deus e nos dos homens, harmonizando, em todos os seus atos, a dilatação da Fé e a dilatação do Império: "Tôda a sua conquista, exclama o autor das Décadas, é com aqueles dois gládios em que Deus pôs o estado de todo o Universo: um espiritual que consiste em a denunciação do Evangelho por todo o paganismo do mundo que tem descoberto, aumentando e dilatando o estado da Igreja, e outro material, com que ofende a perfídia dos mouros, que querem impedir estas obras". (32)

Ficava assim legitimada a conquista: tirar aos que não são membros da Congregação Evangélica o domínio das terras que ocupam e restituí-las ao seu supremo Senhor, para que nelas se realize o plano divino da redenção. (33)

Mais claramente não se poderiam formular as teses justificadoras da política imperial: a) a causa do Império é a causa da Fé; b) a Nação que recebe de Deus tal mandato deve manter-se unida internamente, assim como fiel aos imperativos comuns da cristandade, não pactuando com infiéis e heréticos; c) o emprego da violência não se justifica para impôr a fé cristã, mas para assegurar a liberdade de sua propagação, sendo esta a razão proeminente das expedições às terras ultramarinas.

$\mathrm{E}$ os motivos econômicos? JoÃo dE Barros não os oculta no decorrer de sua obra, tão manifestos eram êles no drama das feitorias e dos mercados de Asia, onde a cobiça tumultuava os corações.

"O mobil econômico das emprêsas ultramarinas, observa Fidelino de Figuerredo, é repetidamente apontado,

(32) Décadas, Parte I, pg. 8.9. Nossos os grifos. Vide, ainda, pgs. 346 e segs.

(33) Hernani Cidade - loc. cit., pg. 211. 
mas JoÃo dE BARros não tem coragem de o apontar como primacial, ou essa verdade repugnava aos seus sentimen‘os de católico, porque é sempre a causa da religião que ocupa o primeiro lugar; mais duma vez parece que, menos sincero, disfarça o grande relevo que as causas aconômicas tinham na determinação dos fatos que narra". (34)

Não cremos, porém, que o historiador quinhentista fosse insincero ou que the fraquejasse o ânimo ante um fato que a olhos modernos pode parecer dominante. Não há em João de Barros o propósito de um disfarce ou de uma cobertura, como se as razões religiosas por êle invocadas fossem de mera conveniência: daquela forma cria efetiva e sinceramente, como era crença comum na cultura lusa, subordinando os fatores econômicos do imperialismo aos motivos da Fé e do heróico afirmar-se da comunidade. (35)

Alguns anos após a publicação das três primeiras partes das Décadas, Giovanni Botero iria dar a lume o seu famoso tratado sôbre a Razão de Estado, nele reservando grande parte à análise dos problemas dos infiéis e dos tráficos mercantís: é possível que nas Décadas de João DE BARros, autor expressamente lembrado, tenha o escritor peninsular colhido elementos para suas conclusões. (36)

\section{$\mathrm{XI}$}

A explicação transcendente do Império, - que iria perder paulatinamente seu impulso religioso originário,

(34) História da Literatura, loc. cit., pg. 218

(35) Como não cremos na insinceridade de JoÃo dE Barros quando, nas Décadas, ergue seu veemente protesto por ter-se trocado o nome de Santa Cruz pelo de Brasil, denominaçāo esta ditada pelo comercio caracteristico da nova terra.

(36) v. Botero, op. cit., L. VII, 10 (pg. 237) 
até se converter em um sistema frio de cálculos e proveitos mercantis - aquela consciência imperial-comunitário-religiosa atinge seu apogeu na epopéia de camõEs, em cujas estrofes vibra a vida do Renascimento ao mesmo tempo heróica e sentimental, religiosa e cruamente mundana.

Sería impossível transladar aquí todos os versos em que o formidável épico estadeia a pujança de seu patriotismo e de suas convicções politicas, orgulhoso de poder: cantar as glorias recentes e reais de seu povo, deante dos. quais, proclamava, devia emudecer o canto dos heróis imaginários de Homero e de Virgilio.

Portugal parece-lhe predestinado à dupla missão de levar leis divinas e humanas a uma grande parte do. mundo, e assim se dirige a seu rei:

"Vós, ó novo temor da Maura lança,
Maravilha fatal da nossa idade,
Dada ao mundo por Deos, que todo o mande
Para do mundo a Deos dar parte grande". (37)

A conquista ultramarina, desde $D$. João I, ressurge no poema segundo um plano conjugado de Fé e de Império, pois o fundador da dinastia de Avis, uma vez lograda a paz interna, é tentado pelo duplo ideal religioso-imperialista:

"Não sofre o peito forte, usado à guerra

Não ter imigo já a quem faça dano;

$\mathrm{E}$ assi não tendo a quem vencer na terra,

Vai cometter as ondas ido Oceano.

Este he o primeiro Rei que se desterra

Da Patria, por fazer que o Africano

Conheça pelas armas, quanto excede

A lei de Christo a lei de Mafamede"

(37) Lusiadas, Canto I, VI.

(38) Lusiadas, IV, XLVIII. 
Daí o rítmo fundamental do poema enaltecendo os efeitos dos audases navegantes lusos,

" $\mathrm{E}$ também as memórias gloriosas

Daqueles Reis, que foram dilatando

A Fé e o Império..." (39)

Missão tão excelsa, que o poeta desejava ardentemente reinfundir na alma de seu povo, cuja decadência o apavorava, só seria possível graças ao espontâneo esforço conjugado de reis e súditos, participes de uma comunidade concreta sempre imbuida

"Daquela Portuguesa, alta excelência

"De lealdade firme e obediência" (40)

Por sua vez, o monarca não se podia ter em conta de dono de haveres e consciências, mas antes devia preferir ser amado como "rei e companheiro", o primeiro na paz e na guerra. Aos olhos do poeta, incendido no valor da monarquia ideal, não podia ser Rei quem não tivesse no mais alto grau as qualidades morais do povo altivo, que

"A rei não obedece, nem consente

Que não for mais que todos excelente" (41)

A virtude do Príncipe é, segundo o poeta, condição da leal obediência dos súditos, consoante lição já contida no Leal Conselheiro e na Virtuosa Benfeitoria. Não nos parece, pois, possa ser atribuido a Giovanni Botero o mérito de ter incluido entre as exigências da razão de Estado as exigências mesmas da noral, considerando, por exem-

(39) Ibidem, I, II.

(40) Ibidem, V. 72.

(41) Ibidem, III, XCIII. 
plo, "necessaria l'eccellenza della virtú nel prencipe", expressões estas quasi camoneanas. (42)

o Príncipe só é digno quando subordina sua força aos ditames da Justiça:
"Quem faz injuria vil e sem razão"
Com forças e poder em que está posto,
Não vence; que a vitoria verdadeira
É saber ter justiça nua e inteira" (43)

Porque o Rei só o é a serviço do povo, cumprindn-lhe assegurar à sua gente

$$
\begin{aligned}
& \text { "as leis iguais, constantes } \\
& \text { Que aos grandes não dêm o dos pequenos". (44) }
\end{aligned}
$$

Não era Camões um sonhador ignaro das fraquezas humanas. Sabia que o bom Governo não pode dispensar o respeito que se liga à severa austeridade. Queria, por isso, um Principe amado sim, mas também temido.

Com razão Pedro Calmon aproximou essa idéia de um "Rei temido e amado" (Lusiadas, X, CXLIV) da passagem de Il principe: "Que melhor, ser amado que temido, ou mais temido que amado? Pode-se responder que o melhor é ser um e outro".

(42) Ábbagnano (op. cit. vol. II, 1, pg. 34) julga ser aquela "la caratteristica del Botero e la sua novitá nei confronti dello stesso Machiavelli". Na realidade, Botero, nesse como em outros pontos, não faz senão repetir ensinamentos de tratados éticopolíticos anteriores. Comparem-se, nesse particular, as considerações que faz sôbre a excelência da virtude no Principe (BoTERo - Della Ragion di Stato, Utet, 1948, Libro I, IX e segs.) e as de Don Duarte no Leal Conselheiro, loc. cit.: ide ambos é fonte primordial a Politica de Aristóteles, que aliás, Botero expressamente invoca.
(43) Lusiadas - X-LVILI
(44) Lusiadas - IX-XCIV
(45) Pedro Calmon - O Estado e o Direito nos Lusiadas, Rio, Lisboa, s. d., pg. 33. Cis. II Principe, Cap. XVII. 
É bem provável que o épico português conhecesse a obra do genial florentino, não só en razão da imensà fama que êste lograra, como também pela variedade de conhecimentos que revela em seus escritos, nos domínios da filosofia, da ciência e das letras (46). Não acompanharia, porém, Machiavell na ressalva pessimista que logo acrescenta ao trecho supra lembrado: "ma, perchè elli é difficile accozzarli insieme (l'amore e il timore), é molto piú sicuro essere temuto che amato, quando si abbia a mancare dell'uno de'dua. Perché delli uomini si puó dire questo generalmente: che sieno ingrati, volubili, simulatori, fuggitori de'pericoli, cupidi di guadagno; e mentre fai loro bene, sono tutti tua, óferonti el sangue, la roba, la vita, e'figliuoli, come di sopra dissi, quando el bisogno é discosto; ma, quando ti si apressa, e'si rivoltano".

Camões tinha outra crença na dignidade do homem, embora soubesse reconhecer quanto podem as forças demoniacas, a cobiça, a adulação, a luxuria, devotando o maior desprezo àqueles que

"Amam somente mandos e riqueza, Simulando justiça e integridade"

(46) v. Pedro Calmon, loc. cit. O escritor brasileiro aduz alguns exemplos que nos parecem idemonstrar o conhecimento que Camões tinha de Machiavelli. Assim é que o florentino, na dedicatória a Lourenço de Medicis, lembra seus conhecimentos adquiridos "con una lunga esperienza delle cose moderne et und continua lezione delle antigue", a que correspondem os versos camoneanos dirigidos ao Rei no fim do poema:

«Nem me falta na vida honesto estudo,

Com longa experiência misturado" (X, 154)

Sôbre a extensão da cultura do poeta vide o estudo de Joaquim dE CARvalho - Estudos sôbre as leituras filosóficas de Camões, in "Estudos sôbre a cultura portuguesa do século XVI", Coimbra, 1947.

(47) Lusiadas, IX, 28. 
O mesmo realismo fê-lo ver quanto de material e de mesquinho se escondia nas empresas lançadas por devoção à patria e à cristandade, bordando êste comentário sombrio à margem das conquistas ultramarinas:

$$
\begin{aligned}
& \text { "Quanto no rico assi como no pobre } \\
& \text { Pode o vil interesse, a sede imiga } \\
& \text { Do dinheiro, que a tudo nos obriga" (48) }
\end{aligned}
$$

Mas Camões, como João de Barros, não reduz as expedições ultramarinas a episódios de tráfico e mercancia: sabe ver nelas também a pura expressão heróica, a eticidade do despreendimento.

A razão de Estado que, na desesperança a-cristã deMachiavelli já adquirira o fio cortante das inexorabilidades causais, ainda se manifesta em termos de razão de Fé no poema da raça lusiada, que, poema também da Cristandade, atinge um de seus pontos culminantes quando a voz do Poeta, alçando-se sôbre os povos e os soberanos: desunidos e em luta, os conclama para a defesa comum de seus valores mais altos.

Seus versos retratam, nas estrofes candentes do VIF Canto, o panorama da Europa se dilaniando ensanguen. tada, enquanto o perigo anticristão a cerca:

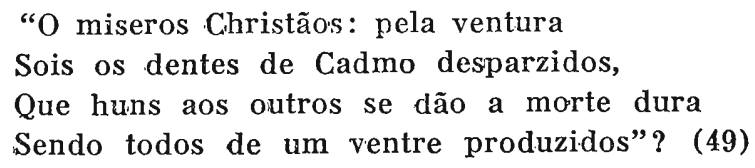

E mais uma vez errompe de seu ser o orgulho de. sua comunidade unida e forte, na unidade e na forca. do ideal que lhe parecia inamovível:

(48) Lustadas - VIII, 96.

(49) Ibidem - VII, 9. E' interessante notar que uma exortação análoga Grovanni Botero redigiu para a 2.a edição de suaa 
"Mas em tanto que cegos, e sedentos Andais de vosso sangue, ó gente insana, Não faltarão Christãos atrevimentos

Nesta pequena casa Lusitana". (50)

\section{XII}

O problema da Razão de Estado, já tão vivo na obra de um historiador e de dois poetas, alcança a sua expressão sistemática na obra de D. Jeronimo Osorio, figura admirável de humanista e de teorizador político.

Integrado na cultura de seu tempo, assinala um momento posterior em contacto com outras concepções de vida, outras valorações da realidade do Estado, representando o seu pensamento uma atitude polêmica, no plano universal, mais do que simples meditação brotada das. circunstâncias peculiares à sua comunidade histórico-nacional, da qual, no entanto, não se divorcia na substância das idéias.

Para os objetivos deste estudo três são os livros de mais direto interesse da autoria de quem foi chamado o Cicero Lusitano: De Nobilitate Christiana; De Justitia, e De Regis institutione et disciplina.

O titulo dessas obras denota por si só grande familiaridade com escritos humanísticos, como os de Pico della Mirandola ou Coluccio Salutati. Seu Humanismo não se resolve, porém, em uma inclinação no sentido de reinstaurar uma antiga tábua de valores, porque desde o início se caracteriza pelo orgulho da comunidade a que pertence e o significado presente de sua grandeza. Não se tratava de buscar na história clássica um modelo para

obra, aparecida em 1590: O derradeiro capitulo de "Della ragion di Stato" corresponde, ponto por ponto, ao Canto VII dos Lusiadas.

(50) Lusiadas - VII. 14. 
a contemplação estética, mas um motivo capaz de ser inserido na nova grande história escrita nos quadrantes do mundo.

Logo no começo de seu tratado sôbre a instituição regia, aponta, com orgulho, a tradição portuguesa de reis que souberam ser homens de sabedoria e de prudência, em contraste com outras terras onde o poder abriu caminhos impensados à malicia dos homens.

Machiavelli, falecido 15 anos antes da publicação de "De Nobilitate Christiana", é uma "presença" na obra de D. Jeronimo Osório. Seu anti-machiavelismo, no entanto, não se confunde com aquela atitude mais ou menos fácil de moralismo abstrato que não supera a problematicidade do florentino exatamente porque não a compreende em seu processo histórico.

Diriamos que em Jerônimo Osório há uma dupla finalidade: afirmar, em primeiro lugar, os valores do Cristianismo perante a descrença de Machiavelli, defendendo-os, não como elementos religiosos, na esfera teológica, mas sim como valores concretos de cultura, ou seja, como cristandade. Essa a missão do "De Nobilitate Christiana". Em segundo lugar, focar o problema do poder político, do Estado em sua realidade intrinseca, para ver se o poder envolve o a-moral ou o imoral: era o problema da legitimidade do poder, no âmago da questão que nos ocupa.

Repugna-lhe a concepção de um Cristianismo de abdicação e de renuncia totais, com a qual se tentara explicar a decadência das antigas "virtú": não só o Cristianismo parece-lhe ser fonte de energias imprevistas, como o demonstra a história dos mártires e dos santos, (humildade cristã e "animi magnitudo" se exigem reciprocamente) mas também é uma condição de agir com serena confiança na identidade substancial da honestidade com as exigências da melhor política. 
Não foi o Cristianismo que provocou a decadência do Império Romano, que tinha a sua queda imanente na grandeza mesma de seu processo: "A mediocridade conserva-se com facilidade, mas as cousas excelsas arruinam-se e desmoronam-se em virtude de sua mesma grandeza" (51).

O Cristianismo ensina-nos, por outro lado, a não nos iludirmos com os êxitos imediatos que às vezes sugerem o caminho da deslealdade e do engano, quando as conveniências do Estado devem ser julgadas com sentido de eternidade, e não com o prisma do fugace e do transitório. Daí as afirmações lapidares marcando sua conciência ética: "as ações honestas e os interesses do Estado são idênticas"; "a honestidade é a melhor política".

$\mathrm{Se}$ o florentino vira o êxito dos principes na aliança feliz da "virtú" e da "fortuna", Jerônimo Osorio proclama, como já o fizera Camões, o princípio da "excelência do principe" como razão de obediência e de gloria duradoura: "omnis vero autoritas est in opinione sapientiae constituta"; "Sapientiae igitur, non fortunae, est omnis felicitas ascribenda"; "autoritas vero tota in sapientia collocanda fit".

(51) "Mediocria facile se sustentant, summa vero sua mole dissipantur et ruunt" De Nobilitate Christiana, Basileia, 1571, pg. 223 e seguintes. Cf. Aubrey F. C. BeLL - O humanista Dom Jerónimo Osório, Coimbra, 1934, pg. 26 e segs.) Em outra obra, De Sapientia, Coimbra, ed 1794, Jerônmo Osónio, em cujo poensamento foi notável a influência da filosofia estoica, precisa o que entende por "sapientia" nestas frases lapidares: "Sapientia (ut Stoici definiebant) est rerim divinarum et humanarum scientia. Hujus studium Philosophia nominatiur. Est autem Philosophiae munus, quid verum, quid rectum, quid simplex fit, inquirere, et inventum mente et ratione complecti, et sapientine verissimae aecretis obtemperare" (pg. 256).

(52) Cr. De Regis Institutione et disciplina, Colonia, 1572, pg. 98 e segs.

(53) $O p$. cit., L. VI, pg. $a_{2}^{2} 7$ e segs. 
A doutrina ética do senhorio, tendo como base a dedicação e o amor dos súditos, e a dedicação e o amor dos súditos fundados na excelência do principe, tôda a maravilhosa lição política que provinha dos ensinamentos da Inclita Geração, reflete-se na obra de Jerónimo Osório, por certo um dos mais notáveis tratadistas políticos de seu tempo.

É essa admirável força histórica e cultural que se sintetisa naquele ensinamento, que bem poderia ser a clave destas divagações, ao fixar êle o destino autêntico de quem governa: "Não governa escravos, mas homens livres, e êstes não devem ser levados a trabalhar pelo medo mas sim pela compreensão do bem comum".

\section{XIII}

Em cotejo com a visão que BuRCKHARDT nos oferece do Renascimento italiano, onde o individuo se projeta como força primordial modelando a sociedade e a história segundo a sua imagem; em contraposição ao homem medieval que só possuia plena conciência de si mesmo como membro de uma raça, de um povo, de uma corporação ou de um partido; em confronto com a perda que o Rensacimento revela do sentido de "congregação cristã", não só em virtude da tolerancia resultante de um alargamento salutar da compreensão da Humanitas como também de suas tendências céticas e agnósticas, a posição do mundo português no início da era moderna é singular. (54)

(54) A propósito do problema religioso na Renascença peninsular, pondera Burckhardt que "da tempo remotissimo il frequente e immediato contatto degli italiani coi Bizantini e coi Mussulmani avea tenuto viva un'abituale tolleranza o indiferenza religiosa, dinnanzi alla quale l'idea etnografica di una Cristianitá occidentale privilegiata perdeva ogni efficacia". (La civiltád del 
Quando, por exemplo um Botero tenta, como vimos, erguer o ideal de defeza da cristandade, sua voz já pertence à Contra-Reforma, nem se amolda mais ao espírito do Renascimento. A exortação de CAMõEs, embora no mesmo sentido, não marca, porém, qualquer solução de continuidade, pois se liga à essência do viver histórico de seu povo, como fato pré-existente aos motivos oriundos de uma crise religiosa à qual ficara estranho: daquele viver histórico a Contra-Reforma na Iberia era, sob certos angulos, menos uma causa do que uma consequência. (55)

Poderia aflorar aqui uma solução simplista, consistente em negar-se o fato do Humanismo e do Renascimento na peninsula ibérica, para assim se salvar um esquema ideal preconcebido. Mas não teria sentido excluir da cultura humanístico-renascentista a afirmação maravilhosa do homem nas "gestae" dos lusos e o canto camoneano dos heróes de um mundo novo.

Na realidade, há uma Renascença portuguesa que se confunde com o seu Humanismo, apresentando características próprias, e, por isso mesmo, uma concepção de razão de Estado que se põe de maneira bem definida perante os padrões vigentes em outras partes da Europa, onde o naturalismo de certas correntes renascentistas, superando a tensão ético-religiosa ainda viva no Humanismo,

Rinascimento in Italia, trad. it., Firenze, 1921, vol. II, pg. 271). Sôbre o "individualismo" como elemento essencial ao Renascimento italico, v. também Cassirer - Individuo e Cosmo nella Filosofia del Rinascimento, trad. it., Florença, 2.a ed., 1950, notadamente pg. 62 e segs. Cf. as reservas de De Ruggiero, loc. cit.

(55) É claro que não pretendemos fazer uma comparação de excelências entre um e outro modo de conceber os problemas religiosos. Verificamos apenas uma diferença, para buscar as razões de uma forma diversa de expressão e desenvolvimento do poder estatal. 
iria alienar a imagem do Homem no trato de seus problemas de convivência, subordinando-o a uma ordem céga para o mundo dos valores éticos.

$\mathrm{Na}$ "pequena Casa Lusitana" o individu'alismo desenfreado e animoso só se manifesta mais tarde, quando o homem se revela incapaz de conservar o "élan" primitivo ou então de adquirir novas energias para multiplicar-se através da solidariedade social, não raro se dissolvendo na triste fruição da riqueza pela riqueza.

Ao lado do individualismo, que todo se desenvolve verticalmente a partir do indivíduo, há lim outro que se sublima na solidariedade do grupo, sem perda do impulso para o alto: "é o individualismo das comunidades concretas, em que os homens se unem a serviço de uma Ideia diretora, respeitando-se uns aos outros através de laçns de expontânea disciplina.

Foi êsse tipo de individualidade que Camões glorificou em seu poema, cantando, ao mesmo tempo, a coletividade a que todos serviam, servindo à humanidade pela revelação de novos valores vitais.

Apreciada a questão com olhos brasileiros, necessário é reconhecer que foi aquele tipo de homem e de comunidade que possibilitou a descoberta de novas terras, assim como a posterior preservação da conquista, assegurando. a unidade de um país imenso como um continente.

Que o espírito de nacionalidade tenha sido essencial no caso excepcional da unidade brasileira, em contraste com os desmembramentos das colonias hispano-americanas, já o reconheceu um dos mais insignes representantes de nossa gente, Joadurm Nabuco, estadista e homem de pensamento, lembrando que se transplantou para a terra americana um sentimento de grupo e de fidelidade à lei, originalmente luso, embora as distâncias e o desamparo gerassem "em tôdas as colonias entregues a sì 
mesmas, um sentimento de nacionalismo à parte, que se revelou nos tempos coloniais".

$\mathrm{Na}$ realidade, seria incompreensivel a unidade de um povo esparramado em ilhas demográficas rarefeitas na vastidão do território, se não o animasse um alto espírito de comunidade, que mantinha os núcleos de povoamento interligados e prontos à defeza recíproca contra os invasores estrangeiros. Donde o equivoco manifesto daqueles que, tendo ido buscar no período que analisamos as raizes do Brasil, não souberam ver senão individualismo desenfreado só suscetivel de dobrar-se à disciplina exterior e precária da ditadura ou do Santo Oficio.

A disciplina, expontânea durou enquanto durou o sentido de comunidade como ưma permeação de serviços sociais expressa na objetividade superior da lei: decaiu abruptamente quando perdeu sua autenticidade, quando a riqueza desencadeou as ondas da cobiça e da ostentação e a própria religião se degradou em fórmulas convencionais e postiças, em um "maquiavelismo" às avessas, sendo a crença intencionalmente reduzida a instrumento de submissão incondicional ao poder e de obscurantismo cultural. (57)

(56) Nabuco - O sentimento da nacionalidade na história do Brasil, in "Obras Completas", São Paulo, 1949, pgs. 431.

(57) Essa tendência oportunista ou pragmática já se esboça na obra de AnTonio DE SouzA MAcedo intitulada Armonia Politica dos Documentos Divinos com as conveniências do Estado, cuija primeira edição é de 1651. Esse livro representa uma notável contribuição das leiras portuguesas à rica ibibliografia dedicada à Razão de Estado no decorrer do século XVII. Seu ilustre Autor já está capacitado de que surgira uma ordem especial de indagações, "reduzindo a razão de Estado a ciência". Apesar de seu cunho ético fundamental deixa transparecer, porém, o modo pragmático de encarar as coisas da religião, como cyando esireve: "He grande segredo de Estado interessar Deos nos desenhos porque o povo os julga por justos, e lhes pronostica bom sucesso". (Op. cit., ed. de 1737, Coimbra, pg. 13). 
Daquela tradição comunitária ficou-nos uma tendência de respeito ao poder enquanto se afirma em razão do bem coletivo e como transformador da vida nacional; uma confiança talvez desmedida nos que governam, donde a perene espectativa de medidas de salvação pública; um sentido quasi que religioso da Lei, das leis iguais que não consagram previlégios, o que constitue reserva preciosa de compreensão da dignidade do Homem.

São Paulo, Abril de 1952.

Atitude explicável em quem tinha em mira apresentar "assunto mais sensivel aos que governão, propondo argumentos da terra, que são mais visiveis". Escrito de significação bem menor é o anterior de BARBos A Homem: "Discursos sôbre a jurídica e verdadeira razão de Estado", 1626, onde a força ética dos escritos de Jerônimo Osório se dilue em um moralismo abstrato e convencional. 